\title{
CENTRAL HEMODYNAMICS AND OXYGEN TRANSPORT IN PATIENTS WITH ACUTE RESPIRATORY DISTRESS SYNDROME CAUSED BY COVID-19 AND THEIR IMPACT ON THE COURSE AND OUTCOMES OF THE DISEASE
}

\author{
Volodymyr Korsunov \\ Department of Anesthesiology, Pediatric Anesthesiology and Intensive Care ${ }^{l}$ \\ korsunoff@ukr.net \\ Marine Georgiyants \\ Department of Anesthesiology, Pediatric Anesthesiology and Intensive Care ${ }^{l}$ \\ vice-rector_nauka@med.edu.ua \\ Vita Skoryk \\ Department of Anesthesiology, Pediatric Anesthesiology and Intensive Care ${ }^{l}$ \\ vitaskoryk@gmail.com \\ ${ }^{1}$ Kharkiv Medical Academy of Postgraduate Education \\ 58 Amosova str., Kharkiv, Ukraine, 61176
}

\begin{abstract}
The aim. Determine hemodynamic status and its impact on oxygen transport, frequency of adverse events and outcomes in patients with severe SARS-CoV-2 associated with acute respiratory distress syndrome (ARDS).

Materials and methods. A single-center prospective comparative study was conducted with 29 patients enrolled over the period of July-October 2020 who suffered a severe course of coronavirus disease and bilateral pneumonia associated with ARDS. Based on the estimated cardiac index (CI), patients were allocated to two groups: Group 1 included 14 patients with severe ARDS and CI $1.9[1.5-2.5] \mathrm{L} / \mathrm{min} / \mathrm{m}^{2}$, whereas Group 2 included 15 patients with CI $4.2[3.2-8.1] \mathrm{L} / \mathrm{min} / \mathrm{m}^{2}(p=0.001)$. Patient's intensive care was regulated by the relevant orders of the Ministry of Health of Ukraine. Statistical analysis of the results was carried out using Statistica 10 software. Statistical significance of parameters was assessed using the non-parametric Wilcoxon criterion. Results were considered significant at $\mathrm{p}$ values $<0.05$. Data are presented as M [25-75]. Relative risk (RR) and odds ratio (OR) of adverse events were calculated.

Results. The severe course of coronavirus disease is associated with significant oxygen transport disorders that increase with hypovolemia. Despite the increase in oxygen delivery in the group with normal CI its high tissue extraction remained, which may be a sign of development mitochondrial distress.

Conclusions. Patients admitted to the ICU with severe COVID-19 may be in a state of hypovolemia and require individual assessment of hemodynamic status and the appointment of infusion therapy. Increased oxygen delivery in patients with normal cardiac index was associated with decreased adverse events rate and statistically significant decrease of mortality rate.
\end{abstract}

Keywords: COVID-19, ARDS, oxygen transport, intensive care, cardiac index.

DOI: $10.21303 / 2504-5679.2021 .001622$

\section{Introduction}

The basis of critical care is this or that way related to control of oxygen transport and prevention of its disorders or correction thereof. When oxygen transport is impaired due to heart failure or hypovolemia (for example due to bleeding), the causes of tissue hypoxia are clear and their correction is not challenging. Oxygen transport disorders are less clear in other severe conditions such as ARDS, and sepsis [1, 2].

According to some study results, among patients admitted to hospital with COVID-19, $33 \%$ manifest with ARDS, $26 \%$ require transfer to the intensive care unit (ICU), $16 \%$ require mechanical ventilation (MV), and $16 \%$ die $[3,4]$. Among COVID-19 patients transferred to ICU $63 \%$ require mechanical ventilation, and $75 \%$ have ARDS [5]. A mortality rate of ICU patients with COVID-19 is $40 \%$, and $59 \%$ of patients are on mechanical ventilation; a mortality rate related 
to COVID-19-associated ARDS is $45 \%$, and ARDS rate among those who did not survive with COVID-19 is $90 \%[6,7]$.

The choice of infusion therapy strategy in patients with ARDS is still controversial. It should be noted that there are several causes of hemodynamic instability in patients with severe coronavirus disease. Firstly, hypovolemia due to fever and restrictive fluid therapy (that was used in early publications as the one preventing development of pulmonary edema). Secondly, the «cytokine storm» may be associated with vasoplegic syndrome which may increase in patients receiving sedatives to synchronize patients with ventilators. The development of the cytokine storm and cytokine circulation in the bloodstream can also affect myocardial tissue and cause both systolic and diastolic dysfunction [8]. The use of positive end-expiratory pressure (PEEP) in patients on mechanical ventilation can affect the right ventricular (RV) relaxation and reduce the left ventricular (LV) systolic function through so-called interventricular interaction. In addition, patients with COVID-19 are prone to hypercoagulation disorders and development of thromboembolic complications which can be associated with critical changes in hemodynamic parameters [9].

Optimal administration of infusion solutions should ensure oxygen delivery avoiding hypervolemia, pulmonary edema that impairs gas exchange. In studies published including patients with ARDS, the liberal type of infusion was associated with prolonged ventilation, stay in ICU, and increased mortality $[10,11]$. With a restrictive type of infusion, investigators obtained better results in terms of oxygenation and shorter duration of mechanical ventilation, but no advantage in survival [12]. Therefore, nowadays, there is no single decision on the choice of infusion strategy for ARDS, with extremely limited data on COVID-19-related ARDS. ARDS is often known to be secondary to shock and may require more aggressive therapy. Bedside ultrasound examination allows to determine the hemodynamic status of the patient and provide targeted therapy, depending on the clinical case.

The issue of oxygen transport in critical conditions became contentious once Shoemaker put forward the hypothesis of «supernormal» oxygen delivery. He defined this condition as cardiac index $(\mathrm{CI})>4.5 \mathrm{~L} / \mathrm{min} / \mathrm{m}^{2}$, oxygen delivery $\left(\mathrm{DO}_{2}\right)>600 \mathrm{~mL} / \mathrm{min} / \mathrm{m}^{2}$, and oxygen consumption $\left(\mathrm{VO}_{2}\right)>170 \mathrm{~mL} / \mathrm{min} / \mathrm{m}^{2}[13,14]$. In his study involving cardiac surgery patients, achieving «supernormal» $\mathrm{DO}_{2}$ values was associated with improved clinical outcomes. Repeated studies confirmed the hypothesis of a positive effect of increased oxygen delivery on preventing organ damage and improving the survival of these patients [14].

However, extrapolation of the hypothesis of «supernormal» oxygen delivery to other critically ill populations did not show any improvement in intensive care outcomes [14].

10 years later, Rivers used a similar method of early targeted therapy with maintenance of central venous saturation of at least $70 \%$ and mean blood pressure (MBP) of at least $65 \mathrm{~mm}$ $\mathrm{Hg}$, which caused repeated interest of intensive care physicians in the hemodynamic status of patients [14]. However, a number of subsequent studies failed to demonstrate the positive effect of early targeted therapy [15-17].

The conducted studies cause a series of discussions that are still ongoing [18-20]. In addition, the methods described above have not been studied before with involvement of patients with severe coronavirus disease complicated by ARDS.

Despite these facts, most of the literature data till nowadays are focused on the treatment of respiratory failure in patients with coronavirus disease, whereas no data are found in the publications of modern scientometric databases regarding hemodynamic effects and their impact on oxygen transport [21].

The aim: to determine the hemodynamic status and its impact on the oxygen transport, frequency of adverse events and outcomes in patients with severe SARS-CoV-2 who develop ARDS.

\section{Materials and methods}

A single-center prospective comparative study was conducted with 29 patients enrolled over the period of July-October 2020 who suffered a severe course of coronavirus disease and bilateral pneumonia associated with ARDS. The study was conducted in the settings of Departments of Anesthesiology, Pediatric Anesthesiology and Intensive Care of Kharkiv Medical Academy 
of Post-graduate Education, in the Intensive Care Unit of the Non-profit Municipal Enterprise of the Kharkiv Regional Council «Regional Clinical Infectious Disease Hospital».

Based on the cardiac index (CI), patients were allocated to two groups: with reduced CI $\left(<3 \mathrm{~L} / \mathrm{min} / \mathrm{m}^{2}\right)$ and normal CI $\left(>3 \mathrm{~L} / \mathrm{min} / \mathrm{m}^{2}\right)$. Group 1 included 14 patients with severe ARDS and CI $1.9[1.5-2.5] \mathrm{L} / \mathrm{min} / \mathrm{m}^{2}$, whereas Group 2 included 15 patients with CI $4.2[3.2-8.1] \mathrm{L} / \mathrm{min} / \mathrm{m}^{2}(p=0.001)$.

Patients were thoroughly examined. The coronavirus disease was diagnosed using PCR with the isolation of SARS-nCoV RNA from the nasopharyngeal wash. Pneumonia was verified by chest CT scan or X-ray. ARDS was diagnosed according to the Berlin definition.

Body mass index (BMI) was calculated using the formula:

$$
\mathrm{BMI}=\text { body weight } / \text { height }^{2}\left(\mathrm{~kg} / \mathrm{m}^{2}\right)
$$

Patients were examined in accordance with the accepted standards including the following tests: FBC, C-reactive protein, procalcitonin, lactate, D-dimer, and blood gas composition. FBC was performed using BC-2800 Mindray analyzer (China). C-reactive protein was evaluated by turbidimetric method (Biosystems kits, Spain). Biochemical tests were performed using Chemray 120 Mindray biochemical analyzer (China). To monitor the haemostatic system condition, D-dimer was determined by the ELISA method (Vector-Best kits, Ukraine).

Using Comen monitors (China), patients heart rate (HR) monitoring was performed using electrocardiography, mean blood pressure (MBP) using oscillometric method and pulse oximetry $\left(\mathrm{SpO}_{2}\right)$, end-expiratory carbon dioxide measurement $\left(\mathrm{etCO}_{2} \mathrm{~mm} \mathrm{Hg}\right)$.

The gas composition of arterial and central venous blood was evalueated using EDAN gas analyzer (China).

Arterial oxygen concentration $\left(\mathrm{CaO}_{2}\right)$ was determined using the calculation:

$$
\mathrm{CaO}_{2}(\mathrm{~mL} / 100 \mathrm{ml})=\left(\left(1.34 * \mathrm{Hb}^{*} \mathrm{SaO}_{2}\right) / 1000\right)+\left(0.003 * \mathrm{PaO}_{2}\right)
$$

where $\mathrm{Hb}$ - hemoglobin, g/L; $\mathrm{SaO}_{2}$ - arterial blood saturation; $\mathrm{PaO}_{2}$ - partial pressure of arterial blood oxygen.

Central venous oxygen concentration $\left(\mathrm{C}_{\mathrm{v}} \mathrm{O}_{2}\right)$ was determined using the calculation:

$$
\mathrm{CvO}_{2}(\mathrm{~mL} / 100 \mathrm{ml})=\left(\left(1.34 * \mathrm{Hb}^{*} \mathrm{SvO}_{2}\right) / 1000\right)+\left(0.003 * \mathrm{PvO}_{2}\right)
$$

where $\mathrm{Hb}$ - hemoglobin, g/L; $\mathrm{SvO}_{2}$ - central venous blood saturation; $\mathrm{PvO}_{2}$ - partial pressure of central venous blood oxygen.

Pulmonary capillaries oxygen concentration $\left(\mathrm{C}_{\mathrm{c}} \mathrm{O}_{2}\right)$ was calculated using the calculation:

$$
\mathrm{C}_{\mathrm{c}} \mathrm{O}_{2}(\mathrm{~mL} / 100 \mathrm{ml})=\left(\left(1.34 * \mathrm{Hb}^{*} \mathrm{SaO}_{2}\right) / 1000\right)+\left(0.003 * \mathrm{PAO}_{2}\right)
$$

where $\mathrm{Hb}$ - hemoglobin, $\mathrm{g} / \mathrm{L} ; \mathrm{SaO}_{2}$ - arterial blood saturation; $\mathrm{PAO}_{2}$ - partial pressure of alveolar blood oxygen.

Oxygen delivery $\left(\mathrm{DO}_{2}\right)$ :

$$
\mathrm{DO}_{2}\left(\mathrm{~mL} / \mathrm{min} / \mathrm{m}^{2}\right)=\mathrm{CI} * \mathrm{CaO}_{2}
$$

Oxygen consumption $\left(\mathrm{VO}_{2}\right)$ was determined using the calculation:

$$
\mathrm{VO}_{2}\left(\mathrm{~mL} / \mathrm{min} / \mathrm{m}^{2}\right)=\mathrm{CI}^{*}\left(\mathrm{CaO}_{2}-\mathrm{CvO}_{2}\right) \text {. }
$$

Index of tissue extraction oxygen was assessed using the calculation:

$$
\mathrm{ITEO}_{2}=\mathrm{DO}_{2} / \mathrm{VO}_{2} \text {. }
$$


All patients underwent daily bedside M-mode echocardioscopy using «Ultima PA» (Ukraine) ultrasound scanner. The left ventricular end-diastolic (EDD), end-systolic (ESD) dimensions and right ventricular EDD were measured. Based on the data obtained using Teichholz L. et al. formula (1976), left ventricular end-systolic (ESV) and end-diastolic (EDV) volumes, stroke volume (SV), and ejection fraction (EF) were calculated.

The cardiac minute output (CMO) was calculated using the formula:

$$
\mathrm{CMO}=\mathrm{SV}^{*} \mathrm{HR}
$$

The cardiac index (CI) was calculated using the formula:

$$
\mathrm{CI}=\mathrm{CMO} / \mathrm{BSA}
$$

where BSA is the body surface area calculated by the Mostller formula.

Intensive care was provided to patients according to relevant orders of the Ministry of Health of Ukraine and included administration of anticoagulants, corticosteroids, infusion therapy, antibacterial agents on demand, remdesivir, use of sympathomimetics and sedatives on demand, treatment of concomitant diseases (coronary heart disease, hypertension, diabetes mellitus, etc.), symptomatic therapy [22-28].

All patients underwent mechanical ventilation using Hamilton C6, Newport E 360t, Monnal 75t, Graph Net and Extend XT machines with assessment of ventilation and pulmonary mechanics parameters: Vt (mL), MV (L/min), f (per min), Pin ( $\left.\mathrm{cm} \mathrm{H}_{2} \mathrm{O}\right)$, Pmean $\left(\mathrm{cm} \mathrm{H}_{2} \mathrm{O}\right)$, PEEP $\left(\mathrm{cm} \mathrm{H}_{2} \mathrm{O}\right), \mathrm{FiO}_{2}(\%)$, $\mathrm{Cst}(\mathrm{mL} / \mathrm{cm}$ w.c.) using graphic monitors. The saturation index (OSI) was calculated using the formula:

$$
\mathrm{OSI}=\left(\mathrm{FiO}_{2} * \text { Pmean } * 100\right) / \mathrm{SpO}_{2},
$$

where $\mathrm{FiO}_{2}$ is the oxygen fraction in the gas mixture, Pmean is the mean airway pressure.

Statistical analysis of the results was carried out using Statistica 10 software. The median, minimum and maximum values, and standard deviation were estimated. Statistical significance of parameters was assessed using the non-parametric Wilcoxon criterion. Results were considered significant at $p$ values $<0.05$. Data are presented as $\mathrm{M}[25-75]$. Relative risk $(\mathrm{RR})$ and odds ratio (OR) of adverse events were calculated.

\section{Results}

The median age of patients in Group 1 was 68 [58.0-72.0] years, and in Group 2 60.5 [45-73.5] years without significant differences between the groups $(p>0.05)$. The body mass index in Group 1 was 39.0 [32.0-46.0] kg/m², and in Group $2-31.0[28.0-36.0] \mathrm{kg} / \mathrm{m}^{2}(p>0.05)$.

FBC in patients of the study groups showed moderate leukocytosis with a neutrophil shift with no significant differences between the groups $(p>0.05)$. C-reactive protein in the study groups was 10-fold higher than normal values and there were no significant differences revealed between the groups $(p>0.05)$. Procalcitonin was $0.2[0.1-1.4] \mathrm{ng} / \mathrm{mL}$ in Group 1 , and $0.6[0.32-0.8] \mathrm{ng} / \mathrm{mL}$ in Group $2(p>0.05)$ (Table 1).

\section{Table 1}

Blood inflammatory response markers in patients of the study groups

\begin{tabular}{lcc}
\hline \multicolumn{1}{c}{ Index, units } & Group $\mathbf{1}(\boldsymbol{n}=\mathbf{1 4})$ & Group 2 $(\boldsymbol{n}=\mathbf{1 5})$ \\
\hline White blood cells, $\times 10^{9} / \mathrm{L}$ & $9.1[7.9-13.4]$ & $10.9[10.8-16.1]]$ \\
Neutrophils, \% & $82.0[79.0-84.0]$ & $91.0[87.0-94.0]$ \\
Lymphocytes, \% & $10.0[9.0-16.0]$ & $6.0[5.0-8.0]$ \\
C-reactive protein, $\mathrm{mg} / \mathrm{L}$ & $58.0[53.0-61.0]$ & $59.3[57.7-126.0]$ \\
Procalcitonin, $\mathrm{ng} / \mathrm{mL}$ & $0.2[0.1-1.4]$ & $0.6[0.32-0.8]$
\end{tabular}


To examine the hemostatic system condition D-dimer was determined and showed the level of 2955.0 [354.0-4450.0] ng/mL in Group 1 and 246.0 [66.0-354.0] ng/mL in Group 2 that reflects the tendency towards hypercoagulation without significant differences between the groups $(p>0.05)$.

The saturation index (OSI) was 18.0 [12.0-24.0] in Group 1 and 12.0 [10.9-18.0] in Group 2 and no significant differences between the groups were detected $(p>0.05)$. The obtained results indicate that patients in both groups have severe ARDS according to the Berlin definition (2012) that requires invasive respiratory support. Patients received pressure-controlled mechanical ventilation in accordance with pulmonary protective principles. The average airway pressure was 16.9 [16.0-21.8] $\mathrm{cm} \mathrm{H} \mathrm{H}_{2} \mathrm{O}$ in Group 1, and 21.0 [14.0-21.8] $\mathrm{cm} \mathrm{H}_{2} \mathrm{O}$ in Group 2 ( $p>0.05$ ). Static compliance did not significantly differ between the groups $(p>0.05)$ (Table 2).

Table 2

Pulmonary mechanics in patients of the study groups

\begin{tabular}{lcc}
\hline \multicolumn{1}{c}{ Index, units } & Group $\mathbf{1}(\boldsymbol{n}=\mathbf{1 4})$ & Group 2 $(\boldsymbol{n}=\mathbf{1 5})$ \\
\hline PEEP, $\mathrm{cm} \mathrm{H}_{2} \mathrm{O}$ & $14[14-16]$ & $14[14-15]$ \\
$\mathrm{P}$ mean, $\mathrm{cm} \mathrm{H} \mathrm{H}_{2} \mathrm{O}$ & $16.9[16.0-21.8]$ & $21.0[14.0-21.8]$ \\
$\mathrm{Vt}, \mathrm{mL}$ & $538.0[410.0-642.0]$ & $515.0[440.0-565.5]$ \\
$\mathrm{C}$ stat, $\mathrm{mL} / \mathrm{cm}$ w.c. & $38.9[34.8-55.8]$ & $37.9[32.6-43.9]$
\end{tabular}

Thus, the patients included in the study had a severe course of coronavirus disease and did not differ significantly between the groups $(p>0.05)$. Therefore, it can be considered that the study groups of patients were comparable in severity of the condition.

The hemodynamic status in Group 2 patients showed a significant increase in EDV, ESV, $\mathrm{SV}$ and CMO. At the same time, what seems to be interesting is the maintenance of normal EF in both groups without significant differences $(p>0.05)$. That is, the decrease in Group 1 CI was associated with hypovolemia rather than primary heart weakness (Table 3).

Table 3

Central hemodynamic condition in patients of the study groups

\begin{tabular}{lccc}
\hline \multicolumn{1}{c}{ Index, units } & Group 1 $(\boldsymbol{n}=\mathbf{1 4})$ & Group 2 $(\boldsymbol{n}=\mathbf{1 5})$ & $\boldsymbol{p}$ \\
\hline $\mathrm{MBP}, \mathrm{mm} \mathrm{Hg}$ & $101.3[83.3-108.7]$ & $100.3[91.0-103.7]$ & $>0.05$ \\
$\mathrm{EDV}, \mathrm{mL}$ & $78.1[51.3-114.3]$ & $144.5[86.5-222.9]$ & 0.001 \\
$\mathrm{ESV}, \mathrm{mL}$ & $16.5[11.3-38.6]$ & $49.1[24.3-150.1]$ & 0.001 \\
$\mathrm{SV}, \mathrm{mL}$ & $52.9[40.0-71.1]$ & $97.2[62.2-150.1]$ & 0.001 \\
$\mathrm{EF}, \%$ & $65.2[62.0-77.9]$ & $67.4[48.0-78.7]$ & 0.51 \\
$\mathrm{CMO}, \mathrm{L} / \mathrm{min}$ & $3.7[3.0-4.0]$ & $9.1[5.8-17.5]$ & 0.01 \\
$\mathrm{CI}, \mathrm{L} / \mathrm{min} / \mathrm{m}^{2}$ & $1.9[1.5-2.5]$ & $4.2[3.2-8.1]$ & 0.001
\end{tabular}

Analysis of arterial blood gas composition was conducted in the study groups. The partial pressure of arterial blood oxygen was 81.0 [72.0-85.0] $\mathrm{mm} \mathrm{Hg}$ in Group 1, and 103.0 [94.0-131.0] mm $\mathrm{Hg}$ in Group 2 with no significant differences between the groups $(p>0.05)$. However, the $\mathrm{PaO}_{2} / \mathrm{FiO}_{2}$ ratio was significantly lower than normal and amounted to 81.5 [70.0-128.0] in Group 1 and 107.0 [95.5-142.0] in Group 2 that corresponds to the severe course of ARDS in all patients $(p>0.05)$. Interestingly, $\mathrm{PaO}_{2}$ and $\mathrm{SaO}_{2}$ were higher in Group 2 than in Group 1. $\mathrm{CO}_{2}$ partial pressure did not significantly differ between the groups, but Group 1 showed a more pronounced tendency to hypocapnia. $\Delta \mathrm{CO}_{2}\left(\mathrm{PaCO}_{2}-\mathrm{etCO}_{2}\right) \mathrm{mm} \mathrm{Hg}$ can be explained by a significant ventilation and perfusion impairment. Arterial blood lactate levels in both groups were higher than normal without significant differences between the groups (Table 4). 
Analysis of the central venous blood gas composition showed no significant differences between the groups $(p>0.05)$ (Table 5).

Table 4

Arterial blood gas analysis in the study groups

\begin{tabular}{lcc}
\hline \multicolumn{1}{c}{ Index, units } & Group 1 $(\boldsymbol{n}=\mathbf{1 4})$ & Group 2 $(\boldsymbol{n}=\mathbf{1 5})$ \\
\hline $\mathrm{pH}_{\mathrm{a}}$ & $7.44[7.29-7.49]$ & $7.39[7.32-7.45]$ \\
$\mathrm{PaO}_{2}, \mathrm{~mm} \mathrm{Hg}$ & $81.0[72.0-85.0]$ & $103[94-131]$ \\
$\mathrm{PaCO}_{2}, \mathrm{~mm} \mathrm{Hg}$ & $32.5[28.3-40.1]$ & $38.1[34.3-46.7]$ \\
$\mathrm{SaO}_{2}, \%$ & $95.0[93.0-97.0]$ & $98.0[97.0-99.0]$ \\
$\mathrm{etCO}_{2} \mathrm{~mm} \mathrm{Hg}$ & $23.0[17.0-28.0]$ & $26.0[22.0-30.0]$ \\
$\mathrm{PaO}_{2} / \mathrm{FiO}_{2}$ & $81.5[70.0-128.0]$ & $107.0[95.5-142.0]$ \\
$\Delta \mathrm{CO}_{2} \mathrm{~mm} \mathrm{Hg}$ & $9.8[7.8-12.1]$ & $13.6[10.2-20.9]$ \\
$\mathrm{Lactate}, \mathrm{mmol} / \mathrm{L}$ & $3.4[2.6-4.4]$ & $5.3[2.8-5.5]$
\end{tabular}

Table 5

Central venous blood gas composition in patients of the study groups

\begin{tabular}{lcc}
\hline \multicolumn{1}{c}{ Index } & Group 1 $(\boldsymbol{n}=\mathbf{1 4})$ & Group 2 $(\boldsymbol{n}=\mathbf{1 5})$ \\
\hline $\mathrm{pH}$ & $7.40[7.30-7.43]$ & $7.38[7.29-7.42]$ \\
$\mathrm{PvO}_{2} \mathrm{~mm} \mathrm{Hg}$ & $49.0[42-50]$ & $48.0[43-55]$ \\
$\mathrm{PvCO}_{2} \mathrm{~mm} \mathrm{Hg}$ & $39.7[36.8-50.7]$ & $48.9[37.2-56.3]$ \\
$\mathrm{SvO}_{2}, \%$ & $82.0[69.0-87.0]$ & $82.0[76.0-85.0]$ \\
etCO$_{2}, \mathrm{~mm} \mathrm{Hg}$ & $25.0[17-31]$ & $26.0[23.0-29.0]$
\end{tabular}

Arterial oxygen concentration was 15.7 [13.3-16.3] $\mathrm{mL} / 100 \mathrm{~mL}$ in Group 1, and 15.9 [13.3-17.9] $\mathrm{mL} / 100 \mathrm{~mL}$ in Group 2 that corresponds to the lower limit of normal and has no significant difference $(p>0.05)$. Central venous oxygen concentration was 11.9 [11.2-13.2] mL/100 mL in Group 1, and 13.0 [10.9-13.8] mL/100 mL in Group 2 and was lower than normal in both groups without significant differences. Pulmonary capillaries oxygen concentration was normal in both groups 15.6 [13.3-16.2] mL/100 mL in Group 1 and 15.8 [13.2-17.8] mL/100 mL in Group 2, respectively.

Group 1 showed a significant reduction in oxygen consumption and delivery compared to Group 2 and normal values. In Group 1, these values corresponded to the lower limit of normal which is due to the severity of the patients' conditions. Oxygen extraction (normal values $0.22-0.30$ ) was 0.35 [0.26-0.51] in Group 1 and 0.38 [0.26-0.49] in Group 2 and had no significant differences, which is explained by a proportional reduction in oxygen delivery and consumption in Group 1 patients (Table 6).

Table 6

Oxygen transport in patients of the study groups

\begin{tabular}{lccc}
\hline \multicolumn{1}{c}{ Index, units } & Group 1 $(\boldsymbol{n}=\mathbf{1 4})$ & Group 2 $(\boldsymbol{n}=\mathbf{1 5})$ & $\boldsymbol{p}$ \\
\hline $\mathrm{CaO}_{2}, \mathrm{~mL} / 100 \mathrm{~mL}$ & $15.7[13.3-16.3]$ & $15.9[13.3-17.9]$ & $>0.05$ \\
$\mathrm{CvO}_{2}, \mathrm{~mL} / 100 \mathrm{~mL}$ & $11.9[11.2-13.2]$ & $13.0[10.9-13.8]$ & $>0.05$ \\
$\mathrm{CcO}_{2}, \mathrm{~mL} / 100 \mathrm{~mL}$ & $15.6[13.3-16.2]$ & $15.8[13.2-17.8]$ & $>0.05$ \\
$\mathrm{VO}_{2}, \mathrm{~mL} / \mathrm{min} / \mathrm{m}^{2}$ & $103.0[69.0-131.0]$ & $268.0[167.0-313.0]$ & 0.008 \\
$\mathrm{DO}_{2}, \mathrm{~mL} / \mathrm{min} / \mathrm{m}^{2}$ & $264.0[246.0-308.0]$ & $652.0[570.0-777.0]$ & 0.008 \\
$\mathrm{O}_{2} \mathrm{ER}$ & $0.35[0.26-0.51]$ & $0.38[0.26-0.49]$ & $>0.05$
\end{tabular}


The average duration of ICU stay was 5 [4-7] days in Group 1 and 8 [5-14] days in Group 2, which indicates a longer life expectancy in Group 2 patients $(p=0.04)$. Frequency of adverse events was also analysed, among which acute kidney injury (AKI), pulmonary embolism (PE) and fatal outcomes can be noted. In Group 1, AKI was diagnosed in 8 patients $(57.14 \%)$, which is almost twice as much as in Group $2-4$ (26.7 \%). However, with calculation of RR 2.14 [0.83-5.56] (>0.05) and OR 3.67 [0.78-17.4] $(>0.05)$ this indicator showed no significant differences between the groups. PE was diagnosed in 5 patients $(35.7 \%)$ of Group 1 and 3 patients $(20.0 \%)$ of Group 2. With RR 1.78 [0.52-6.12] $(p>0.05)$, OR 2.22 [0.42-11.82] $(>0.05)$, there were no significant differences between the study groups.

The overall mortality was $86.2 \%$; however, 14 (100\%) patients died in Group 1 who had reduced CI, and $11(73.3 \%)$ patients died in Group 2 with normal CI. The relative risk of fatal outcomes was calculated: in Group 2, a significantly lower $\mathrm{RR}=1.36[1.01-1.85]$ ( $p=0.046)$ was determined. Thus, maintaining an adequate cardiac index is one of the key therapeutic strategies that are beneficial for the outcomes in patients with respiratory failure caused by coronavirus disease.

\section{Discussion}

The coronavirus disease has rapidly spread around the world over the past year. Most patients have a mild to moderate course, but about $5 \%$ develop complications and require treatment in intensive care units. ARDS is the most common cause for ICU hospitalization [5]. Therefore, key modern guidelines for the treatment of coronavirus disease focus on the treatment of respiratory failure using various methods of ventilatory support $[18,20]$.

Due to insufficient data obtained to determine the optimal management strategy for these patients, basic principles of the Berlin definition are used in the therapy of COVID-19-associated ARDS, namely pulmonary protective ventilation and restrictive infusion therapy [2].

Thus, insufficient attention is paid to the hemodynamic status of patients. This is an important option, as one of the main tasks of intensive care for respiratory failure is to maintain adequate oxygen delivery. A significant share depends on maintaining a normal volemic status.

Our study showed that a significant number of patients admitted to ICU were hypovolemic. Analysis of the blood gas composition in this group shows a significant reduction in oxygen delivery and consumption compared to Group 2. It consequently led to a higher incidence of complications (AKI, PE) and significant increase in mortality.

In Group 2 where normovolemia was maintained, we obtained better intensive care outcomes expressed as a significant increase in life expectancy and decrease in mortality.

However, it remains interesting that even with maintained adequate oxygen delivery in patients, there was a tendency to increased oxygen consumption, which is reflected in high $\mathrm{O}_{2} \mathrm{ER}$ values. This situation can be assumed to be associated with the development of a «cytokine storm» that pathogenetically resembles the course of septic shock. In this case, management of patients with a critical course of COVID-19 should be based on an individual assessment of the clinical condition and probably more aggressive infusion therapy [21].

Therefore, the obtained results suggest the appropriateness to conduct similar studies with a larger patient population. Patients with COVID-associated ARDS probably need extension of recommendations for management, including monitoring of hemodynamics and liberalization of the infusion regimen.

Study limitations. Restrictions due to the involvement of a small sample of patients.

Prospects for further research. Will further develop the study of hemodynamics and oxygen transport in patients with severe COVID-19 with the development of severe ARDS in order to improve the results of intensive care.

\section{Conclusions}

1. The severe and critical course of COVID-19 with the development of ARDS is associated with significant impairments in oxygen transport and consumption aggravated by hypovolemia.

2. In patients with COVID-19 - related ARDS, hypovolemia is associated with a significant reduction in oxygen delivery $\left(\mathrm{DO}_{2}\right.$ Group1 $264.0[246.0-308.0] \mathrm{mL} / \mathrm{min} / \mathrm{m}^{2}$, group 2 - 
$652.0[570.0-777.0] \mathrm{mL} / \mathrm{min} / \mathrm{m}^{2}$ ) and consumption ( $\mathrm{VO}_{2}$ group $1-1103.0[69.0-131.0] \mathrm{mL} / \mathrm{min} / \mathrm{m}^{2}$, group $2-268.0$ [167.0-313.0] $\left.\mathrm{mL} / \mathrm{min} / \mathrm{m}^{2}\right)$ compared to patients with normal CI ( $\left.p=0.008\right)$.

3. The difference between $\mathrm{CO}_{2}$ is explained by severe ventilation and perfusion impairments in patients with COVID-19.

4. Despite the increased oxygen delivery in the group with a normal cardiac index, its tissue extraction remained high 0.38 [0.26-0.49], which might be a sign of the mitochondrial distress.

5. Increased oxygen delivery in patients with a normal cardiac index was associated with reduced frequency of adverse events and significant decrease in mortality $\mathrm{RR}=$ $=1.36[1.01-1.85](p=0.046)$.

\section{Conflict of interests}

The authors declare that they have no conflicts of interest.

\section{References}

[1] Guven, G., Hilty, M. P., Ince, C. (2019). Microcirculation: Physiology, Pathophysiology, and Clinical Application. Blood Purification, 49 (1-2), 143-150. doi: http://doi.org/10.1159/000503775

[2] Ranieri, V. M., Rubenfeld, G. D., Thompson, B. T., Ferguson, N. D., Caldwell, E., Fan, E. et. al. (2012) Acute respiratory distress syndrome: the Berlin Definition. JAMA, 307 (23), 2526-2533. doi: http://doi.org/10.1001/jama.2012.5669

[3] Tzotzos, S. J., Fischer, B., Fischer, H., Zeitlinger, M. (2020). Incidence of ARDS and outcomes in hospitalized patients with COVID-19: a global literature survey. Critical Care, 24 (1). doi: http://doi.org/10.1186/s13054-020-03240-7

[4] Wu, Z., McGoogan, J. M. (2020). Characteristics of and Important Lessons From the Coronavirus Disease 2019 (COVID-19) Outbreak in China: Summary of a Report of 72314 Cases From the Chinese Center for Disease Control and Prevention. JAMA, 323 (13), 1239-1242. doi: http://doi.org/10.1001/jama.2020.2648

[5] Wu, C., Chen, X., Cai, Y., Xia, J., Zhou, X., Xu, S. et. al. (2020). Risk Factors Associated With Acute Respiratory Distress Syndrome and Death in Patients With Coronavirus Disease 2019 Pneumonia in Wuhan, China. JAMA Internal Medicine, 180 (7), 934-943. doi: http://doi.org/10.1001/jamainternmed.2020.0994

[6] Auld, S. C., Caridi-Scheible, M., Blum, J. M., Robichaux, C., Kraft, C., Jacob, J. T. et. al. (2020). Emory COVID-19 Quality and Clinical Research Collaborative. ICU and Ventilator Mortality Among Critically Ill Adults With Coronavirus Disease 2019. Critical Care Medicine, 48 (9), e799-e804. doi: http://doi.org/10.1097/ccm.0000000000004457

[7] Fan, E., Beitler, J. R., Brochard, L., Calfee, C. S., Ferguson, N. D., Slutsky, A. S., Brodie, D. (2020). COVID-19-associated acute respiratory distress syndrome: is a different approach to management warranted? The Lancet Respiratory Medicine, 8 (8), 816-821. doi: http://doi.org/10.1016/s2213-2600(20)30304-0

[8] Ruscitti, P., Berardicurti, O., Iagnocco, A., Giacomelli, R. (2020). Cytokine storm syndrome in severe COVID-19. Autoimmunity Reviews, 19 (7), 102562. doi: http://doi.org/10.1016/j.autrev.2020.102562

[9] Mongan, D., Cannon, M., Cotter, D. R. (2020). COVID-19, hypercoagulation and what it could mean for patients with psychotic disorders. Brain, Behavior, and Immunity, 88, 9-10. doi: http://doi.org/10.1016/j.bbi.2020.05.067

[10] Papazian, L., Aubron, C., Brochard, L., Chiche, J.-D., Combes, A., Dreyfuss, D. et. al. (2019). Formal guidelines: management of acute respiratory distress syndrome. Annals of Intensive Care, 9 (1). doi: http://doi.org/10.1186/s13613-019-0540-9

[11] Warren, M. A., Zhao, Z., Koyama, T., Bastarache, J. A., Shaver, C. M., Semler, M. W. et. al. (2018). Severity scoring of lung oedema on the chest radiograph is associated with clinical outcomes in ARDS. Thorax, 73 (9), 840-846. doi: http:// doi.org/10.1136/thoraxjnl-2017-211280

[12] Alessandri, F., Pugliese, F., Ranieri, V. M. (2017). The Role of Rescue Therapies in the Treatment of Severe ARDS. Respiratory Care, 63 (1), 92-101. doi: http://doi.org/10.4187/respcare.05752

[13] Schumacker, P. T., Cain, S. M. (1987). The concept of a critical oxygen delivery. Intensive Care Medicine, 13 (4), $223-229$. doi: http://doi.org/10.1007/bf00265110

[14] Pinsky, M. R., Teboul, J.-L., Vincent, J.-L. (Eds.). (2019). Hemodynamic Monitoring. Lessons from the ICU. Cham: Springer, doi: http://doi.org/10.1007/978-3-319-69269-2

[15] Mouncey, P. R., Osborn, T. M., Power, G. S., Harrison, D. A., Sadique, M. Z., Grieve, R. D. et. al. (2015). Trial of Early, Goal-Directed Resuscitation for Septic Shock. New England Journal of Medicine, 372 (14), 1301-1311. doi: http://doi.org/ 10.1056/nejmoa1500896

[16] Yealy, D. M., Kellum, J. A., Huang, D. T., Barnato, A. E., Weissfeld, L. A., Pike, F. et. al. (2014). A randomized trial of protocol-based care for early septic shock. New England Journal of Medicine, 370 (18), 1683-1693. doi: http://doi.org/10.1056/ nejmoal401602 
[17] Peake, S. L., Delaney, A., Bailey, M., Bellomo, R., Cameron, P. A., Cooper, D. J. et. al. Goal-directed resuscitation for patients with early septic shock (2014). New England Journal of Medicine, 371 (16), 1496-1506. doi: http://doi.org/10.1056/ nejmoa1404380

[18] Alhazzani, W., Møller, M. H., Arabi, Y. M., Loeb, M., Gong, M. N., Fan, E. et. al. (2020). Surviving Sepsis Campaign: guidelines on the management of critically ill adults with Coronavirus Disease 2019 (COVID-19). Intensive Care Medicine, 46 (5), 854-887. doi: http://doi.org/10.1007/s00134-020-06022-5

[19] Tobin, M. J. (2020). Basing Respiratory Management of COVID-19 on Physiological Principles. American Journal of Respiratory and Critical Care Medicine, 201 (11), 1319-1320. doi: http://doi.org/10.1164/rccm.202004-1076ed

[20] Gattinoni, L., Meissner, K., Marini, J. J. (2020). The baby lung and the COVID-19 era. Intensive Care Medicine, 46 (7), 1438-1440. doi: http://doi.org/10.1007/s00134-020-06103-5

[21] Thalappillil, R., White, R. S., Tam, C. W. (2020). POCUS to Guide Fluid Therapy in COVID-19. Journal of Cardiothoracic and Vascular Anesthesia, 34 (10), 2854-2856. doi: http://doi.org/10.1053/j.jvca.2020.04.049

[22] Orhanizatsiia nadannia medychnoi dopomohy khvorym na koronavirusnu khvorobu (COVID-19) (2020). Nakaz MOZ Ukrainy No. 722. 28.03.2020. Available at: https://moz.gov.ua/article/ministry-mandates/nakaz-moz-ukraini-vid-28032020--722-organizacija-nadannja-medichnoi-dopomogi-hvorim-na-koronavirusnu-hvorobu-covid-19

[23] Pro zatverdzhennia protokolu «Nadannia medychnoi dopomohy dlia likuvannia koronavirusnoi khvoroby (COVID-19)» (2020). Nakaz MOZ Ukrainy No. 762. 02.04.2020. Available at: https://moz.gov.ua/article/ministry-mandates/nakaz-moz-u kraini-vid-2042020--762-pro-zatverdzhennja-protokolu-nadannja-medichnoi-dopomogi-dlja-likuvannja-koronavirusnoi-hvorobi-covid-19

[24] Pro vnesennia zmin do protokolu «Nadannia medychnoi dopomohy dlia likuvannia koronavirusnoi khvoroby (COVID-19)» (2020). Nakaz MOZ Ukrainy No. 852. 10.04.2020. Available at: https://moz.gov.ua/article/ministry-mandates/nakaz-moz-u kraini-vid-10042020--852-pro-vnesennja-zmin-do-protokolu-nadannja-medichnoi-dopomogi-dlja-likuvannja-koronavirusnoi-hvorobi-covid-19

[25] Pro vnesennia zmin do dodatku 6 Standartiv medychnoi dopomohy Koronavirusna khvoroba (COVID-19) (2020). Nakaz MOZ Ukrainy No. 994. 30.04.2020. Available at: https://moz.gov.ua/article/ministry-mandates/nakaz-moz-ukraini-vid-30042020-994-pro-vnesennja-zmin-do-dodatku-6-do-standartiv-medichnoi-dopomogi-koronavirusna-hvoroba-covid-19

[26] Pro vnesennia zmin do Standartiv medychnoi dopomohy Koronavirusna khvoroba (COVID-19) (2020). Nakaz MOZ Ukrainy No. 1411. 16.06.2020. Available at: https://moz.gov.ua/article/ministry-mandates/nakaz-moz-ukraini-vid-16062020--1411-provnesennja-zmin-do-standartiv-medichnoi-dopomogi-koronavirusna-hvoroba-covid-19

[27] Pro vnesennia zmin do protokolu «Nadannia medychnoi dopomohy dlia likuvannia korona virusnoi khvoroby (COVID-19)» (2020). Nakaz MOZ Ukrainy No. 2116. 17.09.2020. Available at: https://moz.gov.ua/article/ministry-mandates/nakaz-moz-u kraini-vid-17092020--2116pro-vnesennja-zmin-do-protokolu--nadannja-medichnoi-dopomogi-dlja-likuvannja--koronavirusnoi-hvorobi-covid-19

[28] Pro vnesennia zmin do protokolu «Nadannia medychnoi dopomohy dlia likuvannia korona virusnoi khvoroby (COVID-19)» (2020). Nakaz MOZ Ukrainy No. 2583. 11.11.2020. Available at: https://moz.gov.ua/article/ministry-mandates/nakaz-moz-u kraini-vid-11112020--2583-pro-vnesennja-zmin-do-protokolu--nadannja-medichnoi-dopomogi-dlja-likuvannja--koronavirusnoi-hvorobi-covid-19 